\title{
BREVES CONSIDERAÇÕES SOBRE O FUTURO DO PROFISSIONAL DO DIREITO: A CRISE DO ESTADO, AS ALTERAÇÕES DE ORDEM INTERDISCIPLINAR E A CRISE DO ENSINO JURÍDICO'
}

\author{
Antonio Carlos Morato \\ Doutorando em Direito Civil pela Faculdade de Direito da USP \\ Professor de Direito Civil e Direito do Consumidor da Faculdade de \\ Direito da Universidade São Marcos e de Direito Civil, Direito Ambiental \\ e Direito do Consumidor da UniFMU
}

\begin{abstract}
Resumo:
A finalidade do presente trabalho é levantar algumas questões que envolvem o operador do Direito no mundo contemporâneo e que talvez venham a influenciar o futuro desse mesmo profissional. Questões como a crise do Estado e a necessidade de conhecimentos interdisciplinares em novos ramos da ciência jurídica (tal como o Direito do Consumidor), bem como as respostas apresentadas até aqui pelo ensino jurídico a tais demandas serão analisadas. Tal estudo desenvolver-se-á sem perder de vista a permanência de algumas críticas às Faculdades de Direito, repetindo argumentos que já eram invocados no século XIX e que continuam a ser apresentados freqüentemente como se estivessem surgindo em pleno século XXI.
\end{abstract}

\section{Abstract:}

The target of the present work is to confront a few questions in the life of the law professional today and maybe will be present in the future of this professional. Questions like the crisis of the State and the interconnection of theory in the other sciences and the new Law camps (like the Consumer Law), as well the answers until now by the law teaching system, whose most relevant aspects are analyzed here, namely. This study makes a demonstration of "new" arguments to analyze the Law Schools of the $21^{\text {th }}$ century who repeats the same argumentation of the $19^{\text {th }}$ century.

1. Trabalho que representou a Faculdade de Direito da Universidade São Marcos c que foi apresentado no XXVIII Encontro Nacional de Faculdades de Direito: $O$ Ensino do Direito no Século XXI, rcalizado na Faculdade de Dircito da UFRS, em Porto Alegre, RS, de 25 a 27 de outubro de 2000. 
Unitermos: Crise do Estado, Ensino jurídico, o futuro do profissional do Direito

Sumário: I. Introdução; II: A crise do modelo jurídico centrado no Estado; III: Perplexidades do profissional do Direito diante das transformações contemporâneas; III.l. Os interesses metaindividuais; III.2. Necessidade de aquisição de um conhecimento interdisciplinar; IV. O ensino jurídico; V. Conclusões.

\section{Introdução}

Queremos iniciar nossa exposição esclarecendo que não pretendemos aqui mais do que apontar algumas tendências nas carreiras jurídicas, com base nas reflexões doutrinárias desenvolvidas até o momento por diversos juristas, analisando ainda alguns dispositivos legais que confirmariam a veracidade de tais constatações.

Pretendemos ainda situar historicamente as discussões acerca do conflito do Direito com os demais ramos do conhecimento, bem como demonstrar que muitas das críticas e sugestões, feitas atualmente, para um aprimoramento do ensino jurídico, já eram realizadas em meados do século passado, estando longe de constituir alguma novidade.

Todavia, advertimos desde logo que o próprio título do trabalho parece excessivamente pretensioso e, por essa razão, é importante deixar claro que as conclusões decorrentes do mesmo nada mais são do que humildes contribuições para uma visão inicial sobre a questão, na condição de um simples observador interessado no tema.

Qualquer ciência humana, pela mutabilidade constante da própria sociedade, não está submetida às mesmas regras de comprovação imediata de uma ciência exata, pois só fatos supervenientes é que poderão comprovar ou não o acerto das conclusões que necessariamente apresentam um caráter de provisoriedade em tal campo.

Assim, desenvolveremos nossa exposição em três eixos básicos, ligados entre si, a serem analisados: a crise de um modelo jurídico centrado no Estado; a perplexidade do profissional do Direito em face de novos conhecimentos que the são exigidos para interpretar a própria legislação e as respostas do Ensino Jurídico às transformações que já ocorreram e às que estão em vias de ocorrer.

Lembramos, também, que a expressão operador do Direito, que basicamente equivale à do profissional do Direito, será utilizada em diversos pontos, até porque mencionada com freqüência nas diversas universidades do País e familiar, portanto, ao público a que se destina esse trabalho. 


\section{A crise de um modelo jurídico centrado no Estado}

Não constitui nenhuma novidade a a firmação de que o Estado se encontra imerso em uma grave crise que refletiria no próprio ensino jurídico, já que este teria no estudo da norma produzida por esse mesmo Estado o seu principal fundamento.

É fato que o Estado tem ocupado um papel central não só na produção, mas também na aplicação da norma jurídica e que a norma posta, nessa ordem de raciocínio, deixaria de ser apenas um reflexo da necessidade de eliminação de um determinado conflito para constituir uma verdadeira afirmação de soberania do EstadoNação.

Com a ascensão do Direito Público, como aponta Louis Assier-Andrieu "desenvolvida no século XIX e no início do século XX, devido à exaltação da função estatal, o Direito é encarnado pelo Estado e o Estado supõe o Direito. Sua unidade é a tal ponto indissociável que, falando de um, fica em geral implícito que se fala também do outro". 2

A soberania de um Estado, nesse contexto, seria expressa por meio da norma, o que explica desde uma compreensível preocupação com a vigência desta em seu território, diante de normas elaboradas por Estados estrangeiros até uma tradicional visão de que, mesmo em tratado no qual é parte, esse Estado só deveria permitir o ingresso da norma oriunda do mesmo, em um nível hierárquico inferior ao da norma constitucional.

Essa discussão é particularmente significativa na União Européia, onde se discute a questão do grau de importância da Constituição diante das Diretivas Comunitárias, sendo que os constitucionalistas apoiam-se na prevalência das constituições, enquanto os internacionalistas europeus normalmente vêm sustentando que os tratados é que deveriam prevalecer sobre aquelas. ${ }^{3}$

2. Cf. Louis Assicr-Andricu. O Dircito nas Sociedades Humanas. tradução de Maria Ermantina Galvão. São Paulo: Martins Fontes, 2000, p. 20.

3. Na verdadc, as Dirctivas da União Européia, ao contrário dos regulamentos, não são auto-aplicáveis, como adverte Pietro Perlingicri, mas "se elas contêm, por exemplo, cláusulas gerais que caracterizam uma determinada matéria regulada pelo Direito Estatal, podem ser utilizadas como integrativas e explicativas de tal disciplina. Uma interpretação em conformidade com a diretiva não atıada, todlavia, pode ser adotada pelo intérprete somente se a norma interna não se apresenta em aberto e insanável contraste e, ao mesmo tempo, permita ao juiz nacional um certo poder de avaliação discricionário (que deve ser distinto da avaliação arbitrária), que possa ser exercido em conformidade com a diretiva " (Ct: Pictro Pcrlingicri. Perfis do Direito Civil: Introdução ao Dircito Civil Constitucional. tradução de Maria Cristina De Cicco. $3^{\text {at }}$ cd. Rio de Janciro: Renovar, 1997. p. 86). 
Um outro desafio enfrentado no âmbito da União Européia é a transparência das decisões, já que a importância dos parlamentos nacionais é reduzida. Tal fato é descrito por Noam Chomsky, pensador e lingüista norte-americano, ao dizer que os europeus, em relação ao comércio internacional (citando o Gatt, na época), "estão preocupados com a distância crescente entre as decisões executivas (secretas) e as instituições democráticas (ou ao menos parcialmente democráticas) tais como os parlamentos, cada vez menos capazes de influenciar as decisões tomadas no nivel da comunidade" ${ }^{4}$

Redução da soberania e ausência de transparência das decisões - porque por vezes a pressão econômica das grandes empresas suplanta os interesses nacionais - são problemas que envolvem necessariamente a integração econômica em grandes blocos.

Não precisamos nos aprofundar tanto na questão, basta lembrar que o conflito entre norma oriunda de tratado e legislação nacional sempre provoca acirrados debates, ainda que os objetivos sejam os mais nobres possíveis.

No caso brasileiro, um bom exemplo é a discussão acerca da aplicação do Pacto de São José da Costa Rica, que exclúa a possibilidade de prisão do depositário infiel; pois, em que pese o fato do art. $5^{\circ}$. $\S 2^{\circ}$ da Constituição Federal visar justamente a ampliação de direitos (no caso o direito à liberdade), possibilitando a inserção de norma mais favorável relativa à proteção de direito humano fundamental em nível constitucional, a solução foi a mais conservadora possivel, ainda que essa interpretação alternativa fosse viável mesmo diante do ordenamento juridico brasileiro. ${ }^{5}$

4. Cf. Noam Chomsky. A Minoria Próspera e a Multidão Inquieta. $2^{\text {a }}$ cd. Brasilia: UNB, 1999. p. 38.

5. Interessante $\mathrm{c}$ inovadora Doutrina foi descnvolvida tanto por Antonio Cançado Trindade quanto por Flávia Piovesan, defendendo que o $\S 2^{\prime \prime}$ do art. $5^{\prime \prime}$ da Constituição Federal cmprestava um stattus de norma constitucional a qualquer tratado que ampliasse norma relativa a dircitos humanos fundamentais, pois o cscopo do $\S 4^{\circ}$ do art. 60 da mcsma Constituição (as chamadas cláusulas pćtrcas quc impossibilitariam mudanças nos dircitos $\mathrm{c}$ garantias fundamentais previstos no art. $5^{\circ}$ ) scria antes de mais nada proteger os dircitos fundamentais de arroubos autoritários c não estagnar esses mesmos dircitos, pois os dircitos fundamentais previstos ali são apenas um mínimo, que pode ir sc ampliando mais c mais no futuro (consultar, para uma análisc aprofundada da questão, a obra de Flávia Piovesan intitulada "Dircitos Humanos e o Direito Constitucional Internacional", publicada pela Editora Max Limonad c já cm sua 4" cdição).

O Supremo Tribunal Federal, cm um primciro momento não cxaminou tal tcoria, discorrendo apenas accrca do eventual conflito infraconstitucional entre a norma do tratado $\mathrm{c}$ as normas internas (como no caso da alicnação fiduciária cm garantia), no recurso cxtraordinário n. 207.532/SP, que teve como rclator o ministro Morcira Alves, c para quem "esta corte, por seu plenário (HC 72131), firmout o entendimento de que, em face da Carta Magna, de 1988, persiste a constitucionalidade da prisão civil do depositário 

Alteraçôes de ordèn interdisciplinar e a crise do ensino juridico

Assim, um Estado tenta afirmar-se diante dos demais não-só por seu idioma, sua cultura, ou mais tradicionalmente até pelo seu poder bélico mas, também, por meio de suas normas e ainda pela interpretação de seus tribunais, mesmo nos paises em que prevalece o Direito Consuetudinário -

Contudo, o interesse econômico pela integração supera, na maioria das vezes, os argumentos jurídicos - normalmente criados em torno da idéia de um Estado soberano invocados pela Doutrina e pelos tribunais.

Não devemos esquecer que, mesmo no plano interno, argumentos de ordem econômica acabam por suplantar, também, direitos assegurados pela própria Constituição, como pudemos testemunhar nos sucessivos planos econômicos dos anos 80 e 90 .

A rigor, o debate não é novo, pois a Economia - e os agentes econômicos, que muitas vezes influenciam o Estado em um determinado sentido sempre é um dado relevante nessa análise.

Basta recordar que, em 1955, San Tiago Dantas, em aula inaugural da Faculdade Nacional de Direito, já afirmava que "o Direito, como técnica de controle

infiel em se tratando de alienação fiduciária, bem como de que o Pacto de São José da Costa Rica, além de não poder contrapor-se à permissão do art. 5", LXVII da mesma Constituição, não derrogon, por ser. norma infraconstitucional geral, as normas infraconstitucionais especiais sobre prisão civil do depositário infiel".

Postcriormentc, o ministro Celso Mcllo, no RE n. 269.661-7-SP cxaminou a questão c alinhou-sc também a um entendimento mais conscrvador, alcgando incxistir "na perpectiva do modelo constitucional vigente no Brasil, qualquer precedência ou primazia hièárquico-normativa dos tratados ou conveņ̣öes internacionais sobre o Direito Positivo interno, sobretudo em face das cláusulas inscritas no texto da Constituição da República, eis que a ordem normativa externa não se superpõe, em hipótese alguma, ao que prescreve a Lei Fundamental da República. Impende salientar; por isso mesmo, que a cláusula inscrita no art. 7". n. 7. da Convenção Americana sobre Direitos Humanos - que omite qualquer referência normativa à possibilidade de decretação da prisão civil do depositário infiel não-vincula o legislador constituinte, que sempre poderá dispor em sentido contrário no próprio texto da Constituição. Sempre reconhecendo a necessária submissão hierárquico-normativa dos tratados internacionais à ordem juridica subordinante consubstanciada na Lei Fundamental da República (ADI 1.480-DF. Rel Min. Celso de Mello) impõe-se acentuar, neste ponto, que não há como emprestar à cláusula inscrita no art. 5". \$ 2", da Carta Politica um sentido exegético que condicione, ou que iniba, ou, até mesmo, que virtualmente inpossibilite o Congresso Nacional de exercer, en plenitude, as tipicas finçẽes institucionais que the foram deferidas pelo documento constitucional, especialmente quando este outorga ao Poder Legislativo expressa autorização para disciplinar e instituir a prisão civil relativamente ao depositário infiel. A ordem constitucional vigente no Brasil não pode sofrer interpretação que conduza ao reconhecimento de que o Estado brasileiro, mediante convenção internacional, ter-se-ia interditado a possibilidade de exercer; no plano interno, a competência institucional que the foi outorgada, expressamente, pela própria Constituição da República. Os tratados internacionais não podem transgredir a normatividade emergente da Constituição, pois além de não disporem de autoridlade para restringir a eficácia juridica dlas cláusulas constitucionais, não possuem força para conter ou para delimitar a esfera de abrangência normativa dos preceitos inscritos no texto da Lei Fundamental" 
da sociedade, vem perdendo terreno e prestigio para outras técnicas, menos dominadas pelo principio ético, e dotadas de grau mais elevado de eficiência. A ciência da administração, a ciência econônica, as ciências que procuram sistematizar as diversas formas de controle social, fazem progressos que algumas vezes colocam os seus métodos e normas em conflito com as normas jurídicas. $E$ o Direito assume, nesse conflito entre um critério ético e um critério puramente pragmático, o papel de força reacionária, de elemento resistente, que os órgãos de governo estimariam contornar para poderem promover por meios mais imediatos e diretos o que lhes parece ser o bem comum" "

No Brasil diversos problemas tornam extremamente complexa a discussão acerca do papel do Estado, pois os tribunais resistem à aplicação da norma oriunda de tratado ao mesmo tempo em que o Poder Executivo, impulsionado pelas forças do mercado, insiste em uma integração em bloco e invoca a todo instante a inevitabilidade do fenômeno da globalização, ao mesmo tempo os tribunais têm sua atuação contestada e defende-se, constantemente, uma mudança no ensino jurídico, visando adaptá-lo a um sistema próximo do consuetudinário, e em soluções alternativas como a via arbitral.

A própria via arbitral cria uma alternativa que coloca em xeque a idéia de Estado, pois se entendermos que a língua é um dos elementos de identidade de um povo, a própria Lei n. 9.307/96 não impede que a sentença arbitral seja redigida em língua estrangeira.

Embora a via judicial continue a exigir que a decisão seja prolatada em língua portuguesa, Carlos Alberto Carmona salienta que a via arbitral possibilita a redação da sentença arbitral em língua estrangeira, pois embora parte da Doutrina discorde, a Lei n. 9.307/97 "não determina que a sentença arbitral seja necessariamente redigida em idioma nacional, e também não obriga a utilização do vernáculo durante o processo arbitral (e para a prática dos atos processuais)" e "enquanto o Código de Processo Civil determinou peremptoriamente (art. 156) que 'em todos os atos e termos do processo é obrigatório o uso do vernáculo a Lei de Arbitragem não estabeleceu esta limitação, e não poderia mesmo fazê-lo, na medida em que podem as partes estipular que os atos processuais da arbitragem sejam todos processados no Brasil, mas a sentença seja proferida fora do território nacional (art. 10, $\mathrm{V}$ da Lei): seria

6. Cf. San Tiago Dantas. "A Educação Jurídica c a Crisc Brasilcira" Encontros da UNB: Ensino Jurídico. Brasilia: UNB, I978-1979, p. 53. 
pouco prático, em tal hipótese, que a lingua empregada fosse necessariamente a portuguesa!" 7

Lembramos que, até recentemente, o Compromisso Arbitral previsto no Código Civil e, posteriormente, no Código de Processo Civil, era apontado como absolutamente inócuo e deslocado da realidade pois polemizava-se acerca da utilização prática do instituto por não contar com a tradicional tutela estatal.

Logo após a Constituição de 1988, invocava-se o art. $5^{\circ}, \mathrm{XXXV}$ daquele diploma legal, a fim de inviabilizar a arbitragem, sob a alegação de que o princípio da inafastabilidade da tutela judicial e o princípio do juiz natural não admitiriam a via arbitral, posicionamento este que foi revisto por boa parte da Doutrina em face da Lei n. $9.307 / 96^{\circ}$

O Estado brasileiro (e certamente não só ele, já que há uma crise global do Estado que, como veremos, ocorre ciclicamente), dessa forma, encontra-se diante de basicamente dois dilemas, um de ordem externa e outro de ordem interna, na produção da norma e na aplicação do Direito.

No plano externo há a expectativa de maior competitividade internacional por meio da integração em um grande bloco econômico, o Mercosul, que exige uma produção legislativa condicionada por interesses nem sempre convergentes, enquanto no plano interno há uma demanda significativa por maior celeridade do Judiciário, tanto pelas grandes empresas como pela população.

Por sua vez, o Legislativo defronta-se com a complexidade crescente dos problemas sociais que exigem, na produção das norınas, a utilização constante de

7. Cf. Carlos Albcrto Carmona. Arbitragem e Processo: um comentário à Lci n. 9.307/96. São Paulo: Mallaciros. p. 161.

8. Nćlson Nery Júnior afirma que "o que se exclui pelo compromisso arbitral é o acesso di via judicial, mas não à jurisdição. Não se poderá ir à Justiça estatal, mas a lide será resolvida pela Justiça arbitral. Em ambas há, obviamente, a atividade jurisdicional" (Código Brasileiro de Defesa do) Consumidor: comentado pelos autores do anteprojeto. $6^{\circ} \mathrm{cd}$. Rio de Janciro: Forcnsc Universitária. p. 511).

Em pcríodo antcrior à cdição da Lci n. 9.307/96, cm que o juizo arbitral neccssitava de homologaçào, o mesmo autor já sustentava que o art. 1.078 do Código de Processo Civil havia cquiparado o juizo arbitral ao juizo cstatal c que "a sentença arbitral deverá ir ao juiz estatal para homologação, imume de defeitos intelectivos e formais, de sorte que as partes possam entendê-la para poder cumpri-la. O juiz estatal nada poderá acrescentar ao laudo arbitral, quer para corrigir-lhe error in judicando, tampouco para consertar-lhe error in procedendo, sua finção é pura e simples, devendo homologar ou-não o laudo. Entender-se o contrário seria admitir-se o exercicio de jurisdição plena estatal pelo juiz togaulo, que não se limitaria a homologar a sentença arbitral" (Princípios do Processo Civil na Constituição Federal. 3" cd. São Paulo: Revista dos Tribunais, p. 86). 
terminologia própria de áreas estranhas ao Direito tradicional, tais como a Química, a Física, a Biologia e outras, além da crescente insegurança gerada pela violência cada vez maior na sociedade brasileira.

Internamente, a Economia contemporânea exige que os conflitos sejam dirimidos em tempo real, enquanto o Estado, via Poder Judiciário, não consegue ir além de soluções apresentadas em tempo diferido, vez que acostumou-se a uma maior maturação das decisões, sem mencionar a sobrecarga de feitos a que é submetido constantemente. Salienta-se que é a situação na qual a própria Administração Pública apresenta considerável parcela de culpa.

Comentando uma série de artigos publicados por José Eduardo Faria no jornal $O$ Estado de S. Paulo, em que este cuida da dicotomia tempo real e tempo diferido, Luiz Sérgio Fernandes de Souza diz que o surgimento de novas esferas de composição dos conflitos parte "também de organismos financeiros internacionais, que reconhecendo o descompasso entre o 'tempo real' da economia e o 'tempo diferido dos tribunais, procuram investir recursos na modernização do Judiciário brasileiro" e "estes investimentos, para além de suprir as necessidades materiais, buscam uma nova orientação da ideologia juridica, que tende a se aproximar cada vez mais da common law"

Longe de serem desinteressadas, o autor ressalta que a ajuda de organismos internacionais (inclusive, como podemos observar, na promoção de diversos seminários realizados em universidades norte-americanas, para os quais são convidados diversos membros das Cortes superioras brasileiras), tem como escopo "otimizar os resultados da transnacionalização dos mercados" sem esquecer que ainda "desenvolvem-se mecanismos de arbitragem que passam ao largo do Poder Judiciário" e que "esta prática, que vinha sido desenvolvida informalmente pelas empresas transnacionais, foi objeto da Lei Federal n. 9.307/96" ?

Logo, as grandes empresas, ao optarem por buscar soluções fora do Estado, retornam ao antigo modelo da Lex Mercatoria, ${ }^{10}$ visando com isso atingir a rapidez decisória imprescindivel à atividade empresarial.

Nesse sentido, Carlos Alberto Carmona ensina que a Lex Mercatoria contemporânea "desenvolve-se a partir de três circunstâncias bem distintas: a afirmação

9. Cf. Luiz Sćrgio Fcrmandes de Souza. “Globalização e Direitos Humanos: cm busca da racionalidade perdida" RT-757, novembro de 1998 , p. 60.

10. Josć Eduardo Faria, em tcsc apresentada no concurso para professor titular da Faculdade de Dircito da Universidade de São Paulo, intitulada “O Direito na Economia Globalizada" (pp. 4-5, nota de 
crescente de práticas contratuais uniformes no comércio internacional, a consolidação de regras autônomas relativamente às legislações nacionais (o que ocorreu especialmente nas relações entre empresas e Estado, pois este raramente aceita submeter-se à lei daquelas - e vice-versa - de tal sorte que os contratos acabam submetidos a principios de Direito Internacional e principios gerais de Direito) e a crescente conscientização dos operadores do comércio internacional da inadequação das leis nacionais para responder os problemas decorrentes de contratos transnacionais" "

Basta observar que, internacionalmente, os litígios são resolvidos na Organização Mundial de Comércio (OMC) e não na Corte Internacional de Justiça, um órgão que acaba por ser simplesmente decorativo.

Passaríamos então a ter novamente não mais um monismo, mas sim um pluralismo jurídico, porque diversas as fontes de produção da norma.

Contudo, devemos afastar qualquer conclusão apressada e lembrar que a História funciona como um pêndulo, retornando a uma situação semelhante acrescida de novas variáveis.

Nesse sentido, insistimos que o fenômeno do pluralismo não é novo, pois a História oscila entre períodos de centralização e descentralização em torno da figura do Estado.

Para tanto, lembramos que após o período de descentralização ocorrido na Idade Média ocorreu, também por necessidade econômica, o reagrupamento em torno da autoridade estatal.

rodapé n. 10), relata que a Lex Mercatoria foi "forjada a partir dos séculos XI e XII com base has necessidades dos comerciantes europets e navegadores empenhados em abrir novos mercados e de contar. com uma ordem juridica que servisse aos seus interesses onde quer que atuassem ", pois a mesma vem a scr "um conjunto de regras e princípios costumeiros reconhecido pela comunidade empresarial caplicado nas transações comerciais internacionais independentemente de interferências governamentais"

Anterior ao Estado Contemporânco, tais normas lidam “com um grupo particular de pessoas (os mercadores) em locais especificos (feiras, mercados, portos, etc.)", sendo diferentes "dlos direitos locais, feudais, reais e eclesiásticos; tem um caráter auto-regulador em escala transnacional; é aclministrado não por juizes profissionais, mas pelos próprios comerciantes, utilizando como critério básico o principio da eqüidade (no sentido inedieval de fairness); e se destaca pela vinculação e segurança propiciada aos contratos, pela diversidade de procedimentos para o estabelecimento, a transmissão e o recebimento dos créditos e pela rapidez e informalidade da adjudicação".

A perda da previsibilidade c transparência que cstavam na origem da Lex Mercatoria, com a cxpansào da cconomia internacional c a diversificação das práticas c costumes do comércio fizcram com que o Estado Contemporânco incorporassc, de forma progressiva cssc "Dircito dos Mcrcadorcs" c, finalmentc, "a evolução do comércio mundial abrin caminho para o aparecimento do Direito Internacional Privado".

11. Cf. Carlos Albcrto Carmona. op. Cit.,. p. 69. 
Gérard Lebrun frisava esse aspecto, ao relatar que "desde o fim da Idade Média, o desenvolvimento da tecnologia comercial e das transações era pouco compativel com ofracionamento dos poderes locais. É no fin do século XIV que nasce um complexo institucional dotado de poder próprio (os primeiros exércitos profissionais aparecem no final do século XIII), encarregado de garantir a segurança e a Justiça, e que se arroga o monopólio da determinação dos direitos e deveres de cada um" 12

Assim como sabemos que o período medieval se caracterizou pela ausência de um poder central, com a divisão deste entre diversos senhores feudais, tal período também caracterizou-se como aquele em que a população transferiu-se maciçamente dos centros urbanos para o campo.

Durante o Império romano, a antiga capital do Império era uma verdadeira metrópole; mas a ausência de segurança, com a invasão de Roma por sucessivas hordas de bárbaros, motivou os habitantes a abandonar a cidade, preferindo locais isolados e fortificados, onde estavam sob a proteção de pequenas autoridades regionais, que durante a Idade Média tornariam-se os conhecidos senhores feudais.

José Reinaldo Lima Lopes descreve bem essa época, ao afirmar que "muito embora os testemunhos da época romana falassem da corrupção dos juizos, da violência dos poderosos sobre os fracos, da venalidade da Justiça, reconhecia-se que uma estabilidade garantia, por exemplo, as viagens, os deslocamentos dentro do Império. Esta rede de comunicações desaparece, como desaparece a moeda" 13

A par disso, a Idade Média caracterizou-se como um periodo de pluralismo jurídico, porque as autoridades eclesiásticas dispunham de normas distintas para aplicação aos seus membros e não podíamos deixar de voltar a esse ponto, não se cogitava da autoridade estatal nos domínios de um senhor feudal pois, quando muito, reconhecia-se a força vinculante do costume naquela localidade e o monarca acabava por ser apenas mais um senhor feudal.

Paulatinamente, passou a existir novamente a centralização em torno da figura do monarca e, em conseqüiência disso, o Estado passou a produzir novamente o Direito, tal como ocorria na antiga Roma, na Grécia, na Babilônia e em outros povos da antiguidade.

12. Cf. Gerard Lcbrun. O que é Poder? São Paulo: Brasilicnsc, 1984. p. 30.

13. Cf. Josć Rcinaldo Lima Lopes. O Direito na História: liçõcs introdutórias. São Paulo: Max Limonad, 2000 , p. 67. 
Afirma-se que atualmente vivemos em uma nova Idade Média, porque o Estado não se encontra mais capacitado a fornecer a segurança esperada e, por isso, proliferam os condomínios fechados, aumenta-se a demanda pela segurança particular, como podemos testemunhar, no caso da Cidade de São Paulo, os exemplos de Alphaville ou de Tamboré.

Aliás, essa situação não ocorre unicamente no Brasil, pois o termo Nova Idade Média foi cunhado por pensadores italianos e reexaminado pelo jurista argentino Ricardo Lorenzetti, que constataram situações idênticas em seus respectivos paises.

Para o jurista citado, a feudalização do Direito decorre de uma tentativa do indivíduo de desvincular-se do Estado, exemplificando com a situação das classes mais favorecidas economicamente, que "vivem em condomínios onde o municipio tem pouco o que fazer", pois "a polícia é substituida por vigilância contratada; a escola puiblica, pela privada, o sistema de saúde, pelos planos de assistência médica pré-contratada; o crédito estatal, pelo crédito privado", concluindo sua análise afirmando que "assistimos, atualmente, a pior das deformações: a Justiça estatal é substituida pela Justiça privada. as pessoas se armam e se defendem por si mesmas ou contratam policiais privados.

Dessa forma, o indivíduo "não necessita do Estado porque tem o seu próprio feudo e por isso dizemos que estamos assistindo a uma nova Idade Média" it

A conclusão de Lorenzetti, abordando a verdadeira ojeriza que esse grupo social tem aos tributos pode ser associada à análise de Walter Vieira do Nascimento, citando Gabriel Ardant, pois é curioso constatar o quanto a noção de tributação associase à idéia de Estado, já que com o "aperfeiçoamento do sistema tributário romano já se fazia a distinção entre imposto direto e indireto" e "quando Carlos Magno (742814) na tentativa de dotar um Estado sem imposto, acabou por abrir as portas para o feudalismo, a partir dai processou-se a rápida desintegração do sistema fiscal romano, então ainda vigente" e, só bem depois "no periodo que vai do século XIII ao princípio do século XVIII, é que teve curso um movimento no sentido da reconstrução dos Estados e da conseqüiente adoção de uma política tributária capaz de acompanhar e atender às necessidades dessa dinâmica" "1s

14. Ricardo Lorenzetti clabora tal análise tendo $\mathrm{cm}$ vista o trabalho dos pensadores italianos Umberto Eco, Furio Colombo c Francesco Albcroni na obra La Nueı'a Edad Media (cm tradução cspanhola da Editora Alianza, 1984) (Cf. Ricardo Luis Lorenzetti. Fundamentos do Dircito Privado. São Paulo: Revistá dos Tribunais, 1998, pp. 53-54).

15. Gabricl Ardant apud Walter Vicira do Nascimento. Lições de História do Direito. 9" cd., Rio de Janciro: Forcnsc, pp. 108-109. 
Anteriormente, é bom lembrar que "entre os romanos, a arrecadação tributária estava estreitamente ligada a uma politica de guerra" e uma antiga prática seguida pelos governantes das províncias romanas "consistia em submeter um questionário às pessoas mais influentes das localidades, a fim de se saber das condições econômicas de cada região com vistas à cobrança de tributos" 16

A História, como se sabe, demonstrou também que nem sempre as hordas de bárbaros que invadiam as províncias romanas eram malrecebidas, até porque os bárbaros não cobravam tributos e, se tais tributos apresentavam aspectos positivos (embora mais visiveis em Roma, como as grandes construções públicas, os aquedutos), também eram vistos freqüentemente de forma negativa, pois alimentavam a corrupção na capital do Império.

A crise do Estado, conseqüentemente, é cíclica e o grande dilema é que os períodos de retomada da centralização do Poder trazem consigo uma série de abusos para que esse mesmo poder possa se consolidar.

Logo, não foi por acaso que a Revolução Francesa, e o próprio liberalismo, foram a resposta ao absolutismo monárquico, mas a própria Revolução que pregava a liberdade só se consolidou em um período centralizador como o de Napoleão Bonaparte.

Aqui, passamos a discutir um novo aspecto da crise do Estado, aspecto este que também é discutido ciclicamente e que pode ser expresso em uma pergunta: como conjugar liberdade e segurança?

No período pós-revolucionário, a França possuía liberdade, mas não possuía segurança e Napoleão Bonaparte teve sua memória reverenciada não-só pelos feitos militares, mas também por ter restituído a segurança das estradas que ligavam Paris às províncias ao colocar efetivos militares que garantiam a segurança ao longo das mesmas.

Também no plano jurídico a contribuição de Napoleão Bonaparte foi importante, pois de acordo com R. C. Van Caenegem "o idealismo ou utopismo do periodo revolucionário desaparecera" e "o Code Civil constitui o testemunho de uma reação sóbria e realista. Depois de dez anos de regime revolucionário, liquidava-se finalmente a ilusão de uma nova sociedade de homens honestos, em que as normas do Direito seriam substituidas por prescrições morais que determinassem uma conduta civica, e os tribunais e julgamentos, por reconciliações amistosas" existindo porém alguns benefícios, pois apesar do Código Napoleônico restabelecer "o Direito e os 
tribunais em seu pleno rigor", "agora o sistema era mais racional e seu funcionamento mais controlável e previsivel do que no ancien régime" 17

Um fenômeno idêntico ocorreu durante o período da Revolução Russa, pois a resposta ao absolutismo czarista concedeu um período de relativa liberdade durante o período inicial daquela Revolução seguido do despótico Governo de Stalin, que paradoxalmente implementou uma série de reformas preconizadas por seus rivais políticos, como era o caso de Trotsky.

Obviamente, podemos argumentar que, tanto na Revolução Russa quanto na Revolução Francesa tais mudanças ocorreram no seio do próprio Estado, mas o raciocínio permanece válido no que tange à constatação de que o poder, e as revoluções, consolidam-se mediante o sacrifício da liberdade humana em troca da segurança proporcionada pelo Estado.

Aliás, o próprio contrato social de Rousseau em um certo sentido já trazia essa idéia, confirmando que todo ser humano abriria mão de parte de sua liberdade para obter a segurança almejada, por meio do Contrato Social, em que "cada um de nós põe sua pessoa e poder sob uma suprema direção da vontade geral e recebe ainda cada membro como parte indivisivel do todo". 18

Porém, o próprio Rousseau afirmava ainda que "renunciar à liberdade é renunciar à qualidade de homem, aos direitos da Humanidade e mesmo aos próprios deveres. Não há indenização possivel para aquele que renuncia a tudo. Tal renúncia é incompativel com a natureza do homem, é privar de toda moralidade os próprios atos e de toda liberdade a vontade. Enfim, é uma convenção vã e contraditória estipular por um lado uma autoridade absoluta, doutro, uma obediencia sem limites" 19

O pensador italiano Norberto Bobbio analisou o pensamento de Rousseau da seguinte forma: "Como não recordar as primeiras célebres palavras com que se inicia o Contrato Social de Rousseau, ou seja: 'O homem nasceu livre e por toda a parte encontra-se a ferros'?" isso porque os seres humanos "de fato, não nascem nem livres nem iguais". pois "são livres e iguais com relação a um nascimento ou natureza ideais, que era precisamente a que tinham em mente os jusnaturalistas quando falavam

17. Cf. R. C. Van Cacnegem. Uina Introdução Histórica ao Direito Privado. tradução de Carlos Eduardo Machado. São Paulo: Martins Fontcs, 1995, p. 9.

18. Cf. Jcan-Jacques Rousscau. O Contrato Social. tradução de Antônio de P. Machado. Rio de Janciro: Edições dc Ouro, 1971, p. 49.

19. Cf. Jcan-Jacques Rousscau. op. cit., p. 43. 
em estado da natureza. A liberdade e a igualdade dos homens não são um dado de fato, mas um ideal a perseguir; não são uma existência, mas um valor; não são um ser, mas um dever ser"

Porém, a positivação de tais valores muda completamente a questão, porque a partir do momento "em que essas teorias são acolhidas pela primeira vez por um legislador, o que ocorre com as Declarações dos Estados Norte-Americanos e da Revolução Francesa" é a certeza de que os direitos do ser humano não são apenas a "expressão de uma nobre exigência, mas o ponto de partida para a instituição de direitos no sentido estrito da palavras, isto é, enquanto direitos positivos ou efetivos" 20

Tradicionalmente, a regra da maioria é apontada como satisfatória para que se entenda consolidada a democracia e, nesse sentido, afirma Celso Fernandes Campilongo que "hoje, tanto o eleitorado quanto o parlamento dão seguidas mostras de serem corpos políticos pouco estimulados ao uso intensivo e proveitoso da regra da maioria. As fontes da legalidade também parecem ser outras. Conseqüentemente, as práticas e os locais para a utilização da regra da maioria mudam ao ritmo das transformações sociais. A regra da maioria é exata em sua dimensão matemática e formal. Mas é também dinâmica e mutável do prisma ético, político e social. Assim como a democracia, o critério do maior número está sempre em construção. Descrever os limites e aporias da regra da maioria, do princípio da legalidade e do Estado de Direito não significa argumentar contra a democracia. Ao contrário, tais descrições funcionam como uma advertência e um alerta: a democracia exige a vigilância constante de suas formas e seus principios" 21

$\mathrm{Na}$ verdade, o conflito segurança $x$ liberdade só pode deixar de existir também por meio de uma participação direta da população, pois como frisava André Franco Montoro, "para enfrentar o grande desafio da injustiça e assegurar a liberdade real, cultores da ciência politica passaram a elaborar um novo conceito de democracia. Não se trata apenas de eleger representantes' para tomar decisões, legislar ou administrar 'em nome' dos cidadãos, mas de assegurar aos múltiplos setores da população meios de 'participar' na medida do possivel da discussão e solução dos problemas que lhe dizem respeito" 22

20. Cf. Norberto Bobbio. A Era dos Direitos. 11"i cd. tradução de Carlos Nelson Coutinho. Rio dc Janciro: Campus, 1992, p. 29.

21. Cf. Cclso Fcrnandes Campilongo. Direito e Democracia. São Paulo: Max Limonad. p. 123.

22. Cf. Andrć Franco Montoro. Estudos de Filosofia do Direito. São Paulo: Saraiva, 1995. p. 213, 
No Brasil contemporâneo, José Eduardo Faria lembra que “o fosso cada vez mais profundo entre o sistema juridico e os interesses conflitantes numa sociedade em transformação, exponenciado pelas tradicionais dificuldades enfrentadas pelo Judiciário para se adaptar aos novos tempos, conduziu a uma progressiva desconfiança tanto na objetividade das leis, como critério de Justiça, quanto na sua efetividade, como instrumento de regulação e direção da vida sócio-econômica. Decorre dai uma certa banalização da ilegalidade e da impunidade que passou a caracterizar a imagem do Brasil contemporâneo - a imagem de que os códigos teriam sido convertidos em simples ficção e de que sua violação sistemática teria sido convertida em regra geral, expressando a falência de instituições jurídico-judiciais, tornadas anacrônicas por não terem sabido renovar-se" 23

A Democracia é constantemente ameaçada, porque como já lembrava Cesare Beccaria em "numa reunião de homens, percebe-se a tendência contínua para concentrar no menor número os privilégios, o poder e a ventura e restando à maioria miséria e debilidade" necessariamente, só "através de boas leis se podem impedir esses abusos. Mas, freqüentemente, os homens deixam a leis provisórias e à prudência ocasional o cuidado de organizar os negócios mais importantes, quando não os confiam à vontade dos que tem interesse em se oporem às melhores instituições e às leis sábias" 24

Operadores do Direito existem mesmo em regimes de exceção e a histeria relativa à segurança presente nos últimos tempos leva muitos a defenderem a instalação de um regime de exceção, forte e supressor das liberdades.

Esse discurso, comum entre a população, paradoxalmente também encontra eco em quem tem uma formação cultural razoável e acredita que a democracia não poderia manter a segurança da coletividade, podemos indagar, com Fábio Konder Comparato, se "é razoável sustentar-se que o regime democrático enfraquece a segurança coletiva, como querem alguns?"'s5

Ensina o ilustre professor que o vocábulo segurança "liga-se à etimologia (se, prefixo provativo $=$ sine + cura $)$ : é a tranqüilidade de ânimo, a isenção de

23. Cf. Josć Eduardo Faria. Direitos Humanos, Direitos Sociais e Justiça. Josć Eduardo Faria (org.). São Paulo. Malhciros, 1998. p. 17.

24. Cf. Ccsarc Beccaria. Dos Delitos e Das Penas. tradução de Torrieri Guimarãcs. São Paulo: Hemus, p. 11.

25. Cf. Fábio Konder Comparato. Para Viver a Democracia. São Paulo: Brasiliensc, 1989. p. 177. 
preocupações, de cuidados" e frisa que a segurança é sempre concreta, pois "não há segurança em abstrato, mas em relação à vida, ao patrimônio, à criação artística, ì salvação eterna, ao amor de uma pessoa, à própria identidade cultural, etc" e "nesse sentido, "a segurança, como a Jjustiça, é um valor-condição, não um valor-escopo" eis que "não se busca a segurança pela segurança, mas como meio de fruição de um bem ou manutenção de um interesse"

Nessa linha de raciocínio, "poder-se-ia tentar explicitar uma oposição fácil entre segurança e liberdade, apresentando aquela como conservação da ordem e esta como condição de progresso; aquela como ausência de riscos e esta como aceitação de riscos; a segurança como sistema de garantias artificiais e a liberdade como manifestação das virtualidades naturais ao ser humano"

Contudo, como já foi demonstrado, a segurança e a liberdade complementam-se, já que "o excesso de segurança acaba por suprimir a liberdade, assim como a total liberdade é a ausência de segurança" pois "para que exista liberdade é indispensável um minimo de segurança, a ausência completa de controle dos riscos que pesam sobre a existência humana frustra qualquer tentativa se decidir ou agir segundo a própria determinação" e "sem um mínimo de liberdade, quando mais não seja para alterar o sistema de garantias, nada é seguro.

Estabelecer um regime de segurança sem liberdade supõe organizar a coação na perfeição, isto é, não apenas dispensar a colaboração dos destinatários das normas de segurança, como também afastar a possibilidade de sua interferência, por minima que seja, no funcionamento do sistema. Ora, isto equivale a colocar todos os membros da coletividade à mercê do titular do poder; ou seja, em estado de total insegurança" 20

Em sua análise histórica, Fábio Konder Comparato frisa que o medo foi o grande responsável pelo rompimento desse equilíbrio precário e o Estado totalitário, que explora o sentimento de insegurança das massas "representa a organização concentrada do terror oficial em substituição à angústia generalizada e informe; ela substitui a insegurança da desordem pela ordem da insegurança" 27

Ao colocar brilhantemente a antinomia entre a insegurança da desordem e a ordem da insegurança, Fábio Konder Comparato aproxima-se de Goffredo Telles

26. Cf. Fábio Konder Comparato. op. cit. pp. 180-182.

27. Cf. Fábio Konder Comparato. op. cit. pp. 184-185. 
Júnior que assinala que conferimos a uma ordem que não nos convêm o nome de desordem, simplesmente porque "ela não é a ordem que queremos, ela não é a ordem que nos agrada, que procuramos, que talvez amamos" pois "na realidade, a ausência de uma certa ordem não é desordem, mas a presença de outra ordem" 28

Sem dúvida, a ordem que convém à segurança efetiva da população é a ordem democrática, única a proteger valores básicos dos seres humanos e em consonância inclusive com os direitos metaindividuais, qualificados como Direitos Humanos de terceira geração, que veremos a seguir.

Isso porque, inclusive na proteção ao meio ambiente, a Democracia é fundamental, vez que experiências passadas demonstram que os regimes de exceção (são bons exemplos tanto a devastação ambiental do Mar de Aral na antiga União Soviética quanto as usinas nucleares instaladas em regiões litorâneas durante o regime militar brasileiro nos anos 70) são verdadeiramente desastrosos também nesse aspecto, o que levou à consagração, no Direito Ambiental, do chamado princípio democrático. ${ }^{29}$

Dessa forma, o Estado não está deslocado de sua função; o seu enfraquecimento, cíclico como demonstramos, não pode impedir seu contínuo aprimoramento no sentido de garantir, apesar de todas as pressões contrárias, os direitos fundamentais da pessoa humana e os novos direitos que surgem.

Cabe aos professores dos cursos juridicos desvendar as estruturas de poder e as implicações decorrentes de um enfraquecimento do Estado para que, em sua atividade profissional, o operador do Direito possa conscientizar-se da realidade que se apresenta.

III. A perplexidade do Profissional do Direito diante das transformações contemporâneas

Abordamos no tópico anterior a questão do enfraquecimento do poder do Estado, o que é fundamental, vez que o operador do Direito lida com estruturas de poder, basicamente oriundas do Estado, mas contemporaneamente não apenas deste. O operador do Direito, ao vincular-se a uma estrutura de poder acaba por ser, na maioria das vezes, malvisto. Tal opinião não é nova, pois Thomas More, em sua obra A Utopia,

28. Cf. Goffredo Tcllcs Júnior. O Direito Quântico: cnsaio sobre o fundamento da ordem juridica. 6" cd. São Paulo: Max Limonad, 1985, p. 245.

29. Paulo de Bessa Antuncs incluiu na rclação dos principios que regcm o Dircito Ambicntal o Principio Democrático c tcm sustentado que "o Direito Ambiental é um Direito que tem uma das vertentes de sua origem nos movimentos reivindicatórios dos cidadãos e, como tal, é essencialmente democrático ". (Direito Ambiental. 2" cd. Rio de Janciro: Lumen Juris, p. 26). 
sublinhava a inexistência de advogados na ilha de Utopia (que acabou por designar todo sonho impossível de ser realizado) já que os "que se esforçam por torcer a lei, $e$ decidir uma questão com a maior astúcia, foram dali excluidos". pois todos "pensam que é preferivel que cada um defenda sua causa e confie diretamente ao juiz o que teria a dizer a um advogado", eis que dessa forma "há menos ambigüidade e rodeio e a verdade se descobre mais facilmente" e conclui seu relato afirmando ser "bem dificil praticar semelhante Justiça nos outros paises, enterrados num montão de leis, tão embrulhadas e tão equivocas", pois "de resto, toda a gente na Utopia é doutor em Direito; porque, repito-o, as leis são em muito pequeno número e a interpretação mais grosseira e mais material é admitida como a mais razoável e mais justa" ${ }^{30}$

Reconhecemos, com pesar, que a profissão de advogado acaba sofrendo um preconceito secular, pois este, por maior que seja a sua honestidade, sempre surge em situações difíceis na vida de alguém e se vencer a causa que defende, esta é vista pelo cliente como excessivamente simples e, se perder, isso certamente, ainda de acordo com o cliente, ocorrerá por fruto da incompetência ou da desonestidade do profissional.

Não-bastasse isso, as demais carreiras jurídicas também deparam-se com a exigência de conhecer não apenas o Direito, mas também áreas do conhecimento até então tidas como irrelevantes para aquele que apresentasse as aptidões básicas para as carreiras jurídicas (que até então exigiam apenas um bom conhecimento humanístico, domínio da língua escrita e falada e conseqüente capacidade de persuasão).

Sabemos que boa parte dos alunos que ingressam nos cursos jurídicos sequer apresentam as capacidades básicas que nos referimos até aqui, só que no futuro certamente as exigências acabarão por se tornar cada vez maiores.

Referimo-nos aqui aos Direitos trans-Individuais (coletivos, difusos e individuais homogêneos - como o Direito Ambiental e o Direito do Consumidor), bem como às questões mais recentes e complexas como a Bioética, com a discussão acerca da possibilidade de criação de seres vivos em laboratórios.

No que tange aos interesses trans-Individuais, particularmente os de origem difusa, Mauro Cappelletti, ainda nos anos 70, afirmava que o Direito, como instrumento ordenador da sociedade, assumiria uma tarefa de dimensões até então ignoradas, pois "os direitos e deveres não se apresentam mais, como nos Códigos tradicionais, de inspiração individualística-liberal, como direitos e deveres 
essencialmente individuais, mas meta-individuais e coletivos", citando como exemplos o Direito Ambiental, o Direito do Consumidor e o direito a uma igualdade religiosa, social e racial que teriam um caráter difuso, por pertencerem à sociedade como um todo.

Prosseguia o autor afirmando que a continuação do modelo individualista, próprio das codificações do século XIX, que atribuía direitos apenas a pessoas individuais acabaria por tornar impossivel uma efetiva proteção dos direitos metaindividuais ou trans-individuais. ${ }^{31}$

Não seria possível, sob um prisma tradicional, precisar que seria o titular do direito à despoluição de um rio, pois ou todos se beneficiariam com a limpeza de suas águas ou continuariam a serem prejudicados pela contaminação da mesma.

O Estado, por sua vez, também não poderia ser o único legitimado para a propositura de ações que protegessem direito dessa natureza, pois nem sempre manifestaria disposição para reprimir a tempo essas violações.

Assim, os Direitos Difusos também apresentam um novo complicador para a questão, pois Estado e Sociedade devem andar juntos e o Estado tradicional, estudado nas faculdades, passa a ser questionado uma vez mais, tornando mais complexa a tarefa do operador do Direito.

\section{III.1. Os Interesses Meta-Individuais:}

Os interesses meta-individuais ou trans-individuais envolveriam os chamados direitos de solidariedade, dos quais para Manoel Gonçalves Ferreira Filho "o mais elaborado é o direito ao meio ambiente".

Tais direitos situam-se em uma seqüência de gerações de direitos, dos quais os primeiros seriam os direitos à liberdade (vida, liberdade, integridade física), os de segunda geração seriam os de igualdade (os direitos dos trabalhadores, os direitos de igualdade da mulher) e os de terceira geração seriam os de solidariedade (entre os quais destaca-se o direito ao meio ambiente).

Manoel Gonçalves Ferreira Filho prossegue em seu raciocínio dizendo que "o reconhecimento dos direitos sociais não pôs termo à ampliação do campo dos direitos fundamentais: Na verdade, a consciência de novos desafios, não mais à vida e à liberdade, mas especialmente à qualidade de vida e à solidariedade entre os seres

31. Cf. Mauro Cappclletti, "Formações Sociais c Intercsses Coletivos diante da Justiça Civil", in Revista de Processo, n. 5- p. 131. 
humanos de todas as raças ou nações, redundou no surgimento de uma nova geração - a terceira -, a dos direitos fundamentais. São estes chamados, na falta de melhor expressão, de direitos de solidariedade, ou fraternidade. A primeira geração seria a dos direitos de liberdade, a segunda, dos direitos de igualdade, a terceira, assim, completaria o lema da Revolução Francesa: liberdade, igualdade, fraternidade" ${ }_{32}$

A preocupação com o meio ambiente saudável surgiu como algo relevante para o ser humano, de acordo com Dalmo de Abreu Dallari, a partir da década de 60, pois a partir daí "foi demonstrada, então, a conjugação de vários fatores que provocam o desequilibrio dos elementos da natureza e criam o risco de exaustão dos recursos naturais" 33

No caso do Direito Ambiental, como aponta Édis Milaré, o desenvolvimento econômico traz um complicador, na medida em que "o processo de desenvolvimento dos paises se realiza, basicamente, às custas dos recursos naturais vitais, provocando a deterioração das condições ambientais em rittmo e escala até hoje desconhecidos. A paisagem natural da Terra está cada vez mais ameaçada pelas usinas nucleares, pelo lixo atômico, pelos dejetos orgânicos, pela 'chuva ácida', pelas indústrias e pelo lixo quimico" ${ }^{34}$

Por isso, discute-se hoje o desenvolvimento sustentável, que deve respeitar o meio ambiente, a tal ponto que a Constituição Federal, ao tratar da ordem econômica, dispõe no art. 170, VI que o meio ambiente deverá sempre ser considerado em qualquer atividade econômica.

A aceitação da idéia de um interesse que não tinha sujeito determinado não foi aceita sem que ocorressem muitas controvérsias e, como demonstra Roberto Senise Lisboa, "a dificuldade inicial em se aceitar tais interesses prendia-se à noção de que o sujeito titular de um bem deveria ser necessariamente determinado, sendo incabivel, na concepção de outrora, o reconhecimento de direitos de sujeito totalmente indeterminado, o que atualmente é compreensivel, em face do Direito Subjetivo Difuso" 35

32. Cf. Manocl Gonçalves Fcrrcira Filho. Direitos Humunos Fundamentais. São Paulo: Saraiva, p. 57.

33. Cf. Dalmo de Abreu Dallari. Direitos Humanos e Cidadania. São Paulo: Moderna, 1998, p. 56.

34. Cf. Édis Milarć. Direito do Ambiente: doutrina, prática, jurisprudência, glossário. São Paulo: Revista dos Tribunais, 2000, p. 34.

35. Cf. Roberto Senisc Lisboa. Contratos Difisos e Coletivos: Consumidor, Mcio-Ambicnte, Trabalho, Agrário, Locação, Autor. São Paulo: Revista dos Tribunais, 1997. p. 51. 

Alterações de ordem interdisciplinar e a crise do ensino juridico

No Direito do Consumidor, Direito meta-individual por excelência ao lado do Direito Ambiental, existe também a proteção a direitos individuais, porque como lembrava o saudoso jurista Carlos Alberto Bittar, "na ânsia de prover as exigências pessoais ou familiares - portanto, sob pressão da necessidade - os consumidores têm sua vontade desprezada, ou obscurecida, pela capacidade de imposição de contratação e, mesmo, de regras para a sua celebração, de que dispõem as grandes empresas, face à força de seu poder negocial, decorrente de suas condições econômicas, técnicas e politicas. A vontade individual fica comprimida; evidencia-se um descompasso entre a vontade real e a declaração emitida, limitando-se à aceitação pura e simples, em bloco, do negócio (contratos de simples adesão)", ${ }^{36}$

Uma curiosidade apontada por Celso Fernandes Campilongo é "assinalar que os chamados interesses difusos, do ponto de vista teórico, ganham corpo no mesmo contexto em que surgem os 'novos atores' e decrescem as virtualidades dos sistemas representativos partidários e corporativos. Partidos e sindicatos atuam, tradicionalmente, na perpectiva classista. Lidam com questões específicas, de recortes demarcados pelos programas partidários e plataformas sindicais" "Os interesses difusos têm configuração completamente diversa. Não se referem a uma classe ou grupo determinada, mas sim a coletividades indefinidas e sujeitos indeterminados. Seus objetos são indivisiveis. Os interesses difusos também envolvem uma intensa conflituosidade de que são portadores esses novos atores exige a ampliação do referencial cognitivo do magistrado, o que gera novas exigências quanto à sua formação técnico-profissional" 37

A hipertrofia legislativa é, de acordo com o mesmo autor, o "reflexo de um Estado que desempenha múltiplas funções e de uma sociedade crescentemente diferenciada e fragmentada" 38

Prossegue Campilongo, nessa linha de análise, afirmando que " $a$ multiplicação das leis - mais uma contingência da sociedade e do Estado do que um desvio do legislador - rompe com a noção de sistema juridico fechado e piramidal.

36. Cf. Carlos Alberto Bittar. Direitos do Consumidor: Código de Defesa do Consumidor. 4" cd. Rio de Janciro: Forensc Universitária, 1991. p. 2.

37. Cf. Cclso Fernandes Campilongo. Direitos Humanos, Direitos Sociais e Justiça. Josć Eduardo Faria (org.). São Paulo. Malhciros, 1998. p. 34.

38. Cf. Cclso Fernandes Campilongo. Direitos Humanos, Direitos Sociais e Justiça. Josć Eduardo Faria (org.). São Paulo. Malhciros, 1998.p. 41. 
Nos 'códigos recentes, a estrutura 'aberta' é ainda mais evidente, o que gera a crítica formalista dos juristas tradicionais a leis como o 'Código de Defesa do Consumidor' e o 'Estatuto da Criança e do Adolescente acusados de pouco técnicos" ${ }^{3}$

$\mathrm{Na}$ verdade, não existe mais a homogeneidade das grandes codificações (como foi o caso do Código Penal, do Código Comercial, Civil e dos Códigos Processuais), vez que os "novos códigos" são necessariamente interdisciplinares, exigindo conhecimentos múltiplos não-só na área jurídica, mas também em outros campos do conhecimento humano.

III.2. Necessidade de Aquisição de um Conhecimento Interdisciplinar:

O profissional do Direito tem, no seu dia-a-dia, uma exigência cada vez maior de aquisição de saberes múltiplos, já não basta o conhecimento jurídico, já não basta o recurso aos peritos judiciais, pois há que se ampliar o conhecimento em razão dos próprios textos legais, que estão sempre a incorporar novos termos técnicos originários de outras ciências.

Basta invocar a questão da ectogênese, Maria Helena Diniz, tratando do tema diz que "essa nova técnica para criação de ser humano em laboratório, mediante a manipulação dos componentes genéticos da fecundação, com o escopo de satisfazer o desejo de procriar de determinados casais estéreis e a vontade de fazer nascer homens no momento em que se quiser e com os caracteres que se pretender, entusiasmou a Embriologia e a Engenharia Genética, constituindo um grande desafio para o Direito e para a Ciência Juridica pelos graves problemas juridicos que gera: sendo imprescindivel não-só impor limitações legais às clinicas médicas que se ocupam da reprodução assistida, mas também estabelecer normas sobre responsabilidade civil por dano moral e patrimonial, que venha causar" ${ }^{40}$

Mauro Cappelletti defendeu a necessidade, em vista dos interesses difusos, de estender os poderes do juiz para que sua decisão produza efeitos não apenas entre as partes, mas sim em face de todos ${ }^{41}$ o que é significativo num caso de poluição

39. Cf. Cclso Fernandes Campilongo. Direitos Humanos, Direitos Sociais e Justiça. Josć Eduardo Faria (org.). São Paulo. Malhciros, 1998. p. 42.

40. Cf. Maria Hclena Diniz. "A Ectogênesc c scus Problemas Jurídicos” Revista do Programa de Pós-Graduação da Faculdade de Direito da Pontificia Universidade Católica de São Paulo-PUC-SP. n. I. São Paulo: Max Limonad, 1995. p. 90.

4I. Cf. Mauro Cappelletti, op. cit., p. 141. 
(enquanto degradação ambiental) ou no caso de um medicamento deteriorado fornecido ao mercado de consumo, já que o objetivo é que cesse a poluição ou ainda que o medicamento deixe de ser comercializado.

Para o magistrado, não basta mais a técnica jurídica, pois hoje sua valoração exigirá não apenas a condição de perito em leis, pois essas mesmas leis trazem em si conceitos com os quais não aprendeu a lidar durante os anos em que cursou a Faculdade de Direito.

No dizer de José Eduardo Faria, "as necessidades práticas dos operadores do Direito exigem novos graus de especialização funcional e técnica em sua formação profissional - graus esses que requerem saberes não apenas extra-dogmáticos como, também, extrajurídicos. Entre outras razões porque, ao lado de suas preocupações de natureza profissional, muitos desses operadores do Direito também vão assumindo no exercicio de suas funções uma postura eminentemente política, engajados em movimentos sindicais, comunitários e populares, valendo-se dos aspectos ambiguos $e$ contraditórios do Direito Positivo para expandir uma 'práxis liberadora' das estruturas normativas, em prol de uma efetiva Justiça material" e "requerendo assim um saber crescentemente multidisciplinar e antiformalista" 42

Mas qual seria o eixo central de um saber multidisciplinar e antiformalista? Seria orientar os alunos em um sentido mais prático, tendo em vista o sucesso profissional imediato ou ainda a aquisição de uma postura crítica diante do Direito Positivo para a adequação à realidade sócio-econômica emergente? ${ }^{43}$

Voltando ao exemplo da arbitragem, esta independe de um conhecimento jurídico do árbitro, a decisão deve revestir-se de forma, mas não precisa, inclusive, ser redigida no vernáculo, como já dissemos anteriormente.

Ana Paula Nascimento Martin, esclarecendo a divisão de funções no Tribunal Arbitral de São Paulo, diz que este "é composto por um corpo de árbitros do qual fazem parte advogados, médicos, engenheiros, contadores, psicólogos, pedagogos e professores, entre outros" sendo que, "de acordo com a natureza do processo a ser julgado, as partes escolherão os árbitros que irão atuar", pois "esses árbitros peritos irão usar seus conhecimentos especificos para orientarem as partes, estando presentes

42. Cf. Josć Eduardo Faria. Direitos Humanos, Direitos Sociais e Justiça. Josć Eduardo Faria (org.). São Paulo. Malhciros, 1998, p. 19.

43. Cf. Josć Eduardo Faria. A Reforma do Ensino Juridico. Porto Alcgrc: Sćrgio Antonio Fabris, 1987, p. 25. 
em todas as fases do processo arbitral junto com advogados que promoverão o entendimento técnico-juridico de cada questão". ${ }^{44}$

Podemós até apresentar objeções à tese de que há uma redução no campo de trabalho do profissional do Direito, alegando que o trabalho dos árbitros peritos são equivalentes ao do perito judicial ou do assistente técnico ou ainda que os antigos juízes classistas, na Justiça do Trabalho, também não necessitavam de formação jurídica.

No entanto, os árbitros peritos decidem em plena igualdade com os árbitros que apresentem formação jurídica, distinguindo-se do perito judicial (pois o magistrado não está adstrito ao laudo do perito) e dos antigos classistas (que podiam decidir, mas freqüentemente delegavam a decisão ao juiz togado pois, na maioria das vezes, examinavam questões relativas a profissões que não faziam parte de seu sindicato, desconhecendo as questões fáticas que justificariam sua presença na Justiça do Trabalho).

A arbitragem, sem dúvida alguma é um instituto útil que colaborou muito para evitar um acúmulo de processos no Poder Judiciários, mas já vimos anteriormente que a Lei n. 9.307/96 surgiu no bojo de uma séria de mudanças oriundas do setor empresarial trans-nacional.

Logo, o operador do Direito deve sempre manter sua consciência social, estando atento às conseqüências e origens dos institutos inseridos no ordenamento jurídico, mas também a consciência social não pode vir desacompanhada de sólida formação cultural.

Talvez seja interessante relembrar os mandamentos do advogado, de Eduardo Coutore, professor catedrático de Direito Processo Civil da Faculdade de Direito de Montevidéu, Uruguai, e falecido em 1956, normalmente conhecidos por constar na página de rosto do livro de Introdução ao Direito, do Professor André Franco Montoro, principalmente pelo $4^{\circ}$ mandamento: "teu dever é lutar pelo Direito; porém, quando encontrares o direito em conflito com a Justiça, luta pela Justiça.

Esse mandamento é muito apreciado pelos estudantes idealistas dos primeiros anos do curso de Direito, mas cabe aqui lembrar ainda os três primeiros mandamentos, não tão, entusiasticamente lembrados pelos alunos e que exigem, nãosó do advogado, mas sim de todo o profissional do Direito o estudo, a reflexão e o

44. Cf. Ana Paula Nascimento Martin, árbitra do Tribunal Arbitral de São Paulo, no artigo "A Altcrnativa da Arbitragem", publicado no Debatendo Direito n. 13, jomal do centro acadêmico XI de Agosto da Faculdade de Dircito da Universidade de São Paulo, p. 23. 
trabalho constante, aqui transcritos" 1 . Estuda - O Direito está em constante transformação. Se não o acompanhas, serás cada dia menos advogado; 2. Pensa-O Direito se aprende estudando, porém se pratica pensando; 3. Trabalha - A Advocacia é uma fatigante e árdua atividade posta a serviço da Justiça" "45

Um outro jurista latino-americano chamado Jorge Witker discutia a multiplicidade de conhecimentos necessários para as carreiras jurídicas, ao salientar que "o extraordinário desenvolvimento tecnológico e a constante destruiç̧ão de teorias e conceitos" acaba por trazer "como conseqüência a absoluta impossibilidade de fixar esquemas rigidos de informação. Deste modo os conteúdos tornam-se instáveis e relativos. Nada é imutável. A técnica moderna de educação muda de orientação e da concepção de informação e conteídos passa para a concepção formativa que se resume na frase 'aprender a aprender' É a revolução tecnológica do nosso tempo que chega à Universidade e às suas metodologias tradicionais" 46

O "aprender a aprender" selecionando o que realmente interessa ao operador do Direito é uma dificuldade não-só dos cursos jurídicos, mas também da Escola em geral, pois como bem lembra Rubem Alves, "às vezes os nossos problemas não decorrem de nossa falta de conhecimento, mas antes de seu excesso"

Rubem Alves insiste no fato de que o conhecimento deve ter um sabor, que deve ser agradável aprender, e talvez a sabedoria consista justamente em saber selecionar o conteúdo que pretendemos ministrar em sala de aula, em suas palavras: "os antigos usavam a palavra sapiência. Sapiência quer dizer conhecimento que tem sabor. Saber é sentir o sabor" sem esquecer a utilidade do conhecimento, buscando sempre uma visão integral do ser humano.

Afinal, ninguém pode passar todo o tempo alheio às circunstâncias sociais, sem que se perca parte do todo, não adianta estudar a norma pela norma, sem ter em conta a sociedade à qual se destina, pois Rubem Alves lembra ainda que, apesar de relativamente normal para especializar-se em uma atividade humana, viver alheio a todo o resto nem sempre é desejável pois "sempre que a inteligência se destaca de um lado, alguma coisa fica esquecida do outro" e nesse aspecto as exigências da especialização seriam úteis apenas em princípio, pois "para nos especializarmos em

45. Cf. Eduardo Couturc. Os Mandamentos do Advogado. $3^{\prime \prime}$ cd. tradução de Ovídio A Baptista da Silva c Carlos Otávio Athaydc. Porto Alcgrc: Sćrgio Antonio Fabris. pp. 7.

46. Cf. Jorge Witker. O Direito na América Latina: conteúdo c cnsino. tradução de Manucla Lcandro. Coimbra: Centro dc Estudos Juridicos, 1975. p. 18-19. 
algo é necessária aquela intensidade de concentração que nos obriga a esquecer o resto-é graças a esta disciplina que temos pianistas, poetas, cirurgiões e mecânicos" 47

Saber selecionar o conteúdo a ser ministrado é essencial em qualquer nível de ensino, seja ele fundamental, médio ou superior, porque senão chegaremos a absurdos como o relatado por Ezequiel Theodoro Silva, em que uma aluna de pósgraduação, que lecionava na rede pública estadual, ensinava semiótica aos alunos do nível fundamental ( $5^{\text {a }}$ série), reclamando que eles não compreendiam o tema discutido (teoria dos signos de Charles Peirce). ${ }^{48}$

Guardadas as devidas proporções verificamos que, por vezes, empolgados com as teses que defendem no pós-graduação, muitos professores de Direito insistem em discuti-las, por maior que seja sua complexidade, com os alunos de graduação, deixando, inclusive, de abordar temas absolutamente necessários ao cumprimento do programa e que seriam muito mais úteis na vida profissional do aluno.

\section{O Ensino Jurídico}

Um aluno do Curso de Direito pode ter se interessado pelas carreiras jurídicas por diversos motivos, mas sem dúvida os mais comuns são a perspectiva de ascensão social e um nobre sentimento de Justiça que normalmente permeia os primeiros anos e é praticamente esquecido, lamentavelmente, nos últimos anos da Faculdade, com exceção talvez dos discursos de formatura.

É comum também que o aluno se ofenda com qualquer alusão à eventual má-fé de algum operador do Direito ou às freqüentes alusões quanto à honestidade na carreira escolhida, mas é conveniente lembrar, desde logo, que Thomas More ironizava, séculos atrás em sua obra Utopia, como já observamos em tópico anterior.

Vamos agora discutir um outro aspecto extremamente importante nas discussões sobre a reforma do ensino jurídico, não o "a quem ensinamos?", nem o "o que ensinamos?" mas o que às vezes é muito negligenciado, a questão do "como ensinamos?"

Maurício Portugal Ribeiro constata que, no atual ensino jurídico "os alunos são meros espectadores" tendo como função apenas servir como um "receptáculo das informações transmitidas pelo mestre", assim os professores apenas

47. Cf. Rubem Alves. Estóricus de Quem Gostu de Ensinur. 17" cd. São Paulo: Cortez, 1994, pp. 15-30. 48. Cf. Ezcquicl Theodoro Silva. Magistério e Mediocridade. 2" cd. São Paulo: Cortez, 1993, pp. 23-24. 
avaliam a capacidade de absorção e memorização dos alunos, pressupondo que "em momento oportuno, os alunos poderão aplicar à realidade as teorias apreendidas durante o curso de Direito", mais ou menos "como se a teoria mapeasse os caminhos parta atingir um fim predefinido"

Nessa concepção, "a teoria deve sempre preceder a práxis, vez que espera-se que funcione como guia que permita distinguir as soluções verdadeiras das falas. Trabalha-se, em tais sistemas de interação, com paradigmas do Direito e de Ciência do Direito do princípio do século XIX" sendo o principal problema desse método que esta "não capacita o discente para manipulação crítica das teorias juridicas". concebendo "o operador do Direito como técnico que aplica teorias neutras a problemas que se repetem"

O ensino torna-se rapidamente defasado, pois "numa sociedade em que as mudanças se realizam cada vez mais rapidamente, a obsolescência das teorias transmitidas nas escolas de Direito é uma fatalidade absolutamente previsivel" o que se pretende para os operadores do Direito do século XXI é que estes estejam preparados "para lidar com situações novas, com situações imprevistas e cuja solução não possa ser dada, sem mais, a partir dos parâmetros legislativos e jurisprudenciais existentes" 49

Poderia um ensino mais próximo da prática sanar essa obsolescência?

De acordo com Eduardo Oliveira Leite, as críticas centravam-se nas aulas expositivas, "como se todas as deficiencias profissionais do futuro advogado decorressem do método de ensino adotado" e "assim, suprimiu-se sistematicamente a exposição-possivel tão somente entre os professores realmente capazes e portadores de extensa bagagem cultural - e adotou-se, indiscriminadamente o sistema de seminários e o estudo de casos (copiado do 'case study' da universidade norteamericana)" 50

No Brasil, essa linha de trabalho teve grande impulso com o CEPED "resultado da assistência norte-americana (USAIx Fundação Ford) para a instituição de uma nova concepção do ensino juridico no Brasil, centrou todo seu esforço na

49. Cf. Maurício Portugal Ribciro. "O Dircito Contcmporânco c a Mctodologia do Ensino do Dircito" Dircito Global. São Paulo: Max Limonad, 1999, pp. 104-105.

50. Cf. Eduardo de Olivcira Lcitc. "A Aula cm Dircito" Seis Temas sobre o Ensino Juridico. organizada por Gctulino do Espirito Santo Macicl c João Bosco da Encanação. São Paulo: Robc Editorial, 1995, pp. 20-23. 
profissionalização, adotando como metodologia didática os case study contrariamente à tendência européia do ensino jurídico propugnando um estudo humanista e cientifico. A tentativa de contornar a dicotomia ciência x prática foi objeto do magnifico Encontro Nacional de Faculdades de Direito, na cidade de Maceió, em 1981, que se encerrou com a recomendação de um currículo minimo, de caráter eclético, aos cursos juridicos"

Mas Eduardo Oliveira Leite lembra também que "embora afirmando que a experiência do CEPED foi um sucesso, no que se referiu a formação de advogados especializados para a demanda das empresas multinacionais (vivia-se a euforia do fenômeno multinacional) e é forçoso reconhecer que tal experiência introduzia no Brasil uma prática de ensino alheia a nossa realidade juridica, estranha a nossas raizes culturais, com resultados altamente discutiveis"

Em suma, segundo o autor, "a verdade é que, a partir da experiência do CEPED, as duas técnicas, do case study e a do seminário, com visivel preferência pela primeira, se introduziram no Brasil e desde aquela época têm sido indiscriminadamente utilizadas como solução a todos os problemas de caráter metodológico" e $o$ 'case study "passou a ser a própria aula, quando, na realidade, é apenas um elemento de apoio na elucidação das questões mais controvertidas detectadas no ato didático"

Concluindo com Eduardo Oliveira Leite, sem o estudo prévio da matéria, "nem a norma, nem o caso são, por si só, suficientes. É imprescindivel a relação entre um e outro sob risco de se comprometer a validade do método empirico dialético" 51

Luiz Eduardo W. Wanderley ressalta que "no século presente, de forma gradual e irresistivel, foram os objetivos, métodos e técnicas do sistema norte-americano que penetraram a América Latina, principalmente no campo das ciências exatas, mas também com influência nos demais campos. No caso brasileiro, esta influência foi decisiva na reforma universitária consentida que vigora desde 1968" 52

André Franco Montoro também sempre defendeu que o transplante de uma doutrina, um instituto ou um método "significa introduzir com ele, em nosso meio, um elemento cultural cujo 'sentido' ou 'finalidade' não corresponde à nossa

51. Cf. Eduardo de Olivcira Lcitc. op. cit., p. 23.

52. Cf. Luiz Eduardo W. Wanderlcy. O quéé Universidlacle. São Paulo: Círculo do Livro (cncadernaçào por liccnça cditorial da Editora Brasiliensc S/A), 1992, pp. 133-134. 
situação e aos nossos interesses" "e na formação dos nossos futuros juristas é indispensável salientar a importância fundamental de um pensamento e de soluções autenticamente nacionais na obra urgente de nosso desenvolvimento" 53

Contudo, em que pesem as críticas, em parte procedentes, acerca da influência norte-americana na opção pelo método dos seminários, lembramos que já no século XIX a inserção de casos práticos era defendida nas faculdades de Direito brasileiras, mesmo antes do desenvolvimento do estudo dos casebooks, na Faculdade de Direito de Harvard, em 1870.

O deputado Joaquim Vilela, em 1851, indagava "por que razão se ocupam muito mais os moços com a literatura de fiç̧ão e a poesia do que com os graves estudos juridicos? Não será certamente por falta de aptidões, mas porque o Direito se ensina rebarbativamente, sem que se lhes desperte o espirito da iniciativa, transformadas as aulas em meros solilóquios professorais" e defendia "multipliquemse os exercicios escolares; distribuam-se casos juridicos a serem analisados e discutidos. Debatam-se nas aulas as decisões judiciárias sobre a matéria de cada cadeira, desenvolvendo nos alunos o talento crítico, a precisão das investigações, o desembaraço nos argumentos; o destemor das autoridades; a confiança no seu próprio talento e ainda introduzam-se os discípulos nos pretórios, nos tribunais, obrigando-os a apresentar atestados de trabalhos de prática, e ter-se-á renovado o curso de Direito para que desempenhe as altas funções que dele exigem as tendências democráticas, as aspirações da ciência e as necessidades nacionais" 54

Segundo Allan Farnsworth, nos EUA, "a introdução do método da jurisprudência data da publicação em 1871 de um repertório de casos contratuais, de autoria de Christopher Columbus Langdell, ${ }^{55}$ professor da Faculdade de Direito de Harvard, contendo uma coleção ordenada de casos e respectivas decisões pelos tribunais superiores, para uso dos estudantes", vez que "a partir do momento em que

53. Cf. André Franco Montoro. op. Cit., pp. 90-91.

54. Cf. Albcrto Venâncio Filho. Das Arcaclas ao Bacharelismo. $2^{a}$ cd. São Paulo: Perspectiva, 1982, p. 64.

55. Cf. E. Allan Farnsworth. Introdução ao Sistema Juridico dos Estados Unidos. tradução de Antonio Carlos Diniz de Andrada. Rio de Janciro: Forcnsc, 1963, p. 25.

Na nota de rodapć n. 10, na mesma página citada, E. Allan Farnsworth relata que "Christopher Columbus Langdel! (1826-1896) foi um advogado de Nova Iorque, que sc tornou professor de Dircito na Faculdade de Harvard $\mathrm{cm} 1870$. Scu principal mérito como professor c mais tarde como dirctor foi a introdução do mćtodo jurisprudencial". 
os professores de Direito principiaram a fornecer a seus alunos coleções de jurisprudência, iniciou-se a tendência a abandonar o método tradicional de preleções e passou-se ao método de propor questões e discutir com os estudantes os casos por eles previamente estudados - em suma, o chamado 'método socrático"' e Christopher Columbus Langdell concluiu assim "que a maneira mais fácil e breve de dominar os poucos princípios básicos nos quais se baseia o Direito era estudar as decisões nas quais se torna efetivo" 56

Talvez a solução adequada seja utilizar os seminários, unindo-se o método das aulas expositivas ao método dos casos práticos; um bom exemplo seria o Curso de Direito Civil do professor Arnoldo Wald, que disse querer reunir "num trabalho o livro de texto e o livro de casos, facilitando assim a orientação prática que necessariamente o ensino jurídico deve aceitar em nossos dias, para evitar que se torne inócuo ou inadequado em relação às condições de vida do nosso pais" 57

Não podemos obviamente, vivermos mergulhados em pura abstração, pois como ensina Tércio Sampaio Ferraz Júnior, "embora o positivismo jurídico radical não corresponda à concepção mais aceita pela doutrina, a compreensão dominante da norma continua a vê-la como um imperativo acabado edado antes do caso concreto, ao qual ela se aplica. Neste esquema usual de captação da norma pela teoria jurídica ocorre uma espécie de vácuo significativo, em que a norma não é nem realidade, nem a situação à qual ela se aplica, mas uma entidade independente que faz, às vezes, da teoria da norma uma espécie de discurso vazio ou, pelo menos, equivocadamente abstrato. Sabemos de que estamos falando quando perguntamos a propósito de uma lei promulgada ontem, ou de uma sentença prolatada no tribunal, ou de um contrato firmado em nossa presença, etc. Mas a busca da norma jurídica em todos esses fenômenos parece uma empresa demasiadamente abstrata que acaba por construir seu objeto antes mesmio de começar a discorrer sobre ele" 58

A aplicação da norma não é mecânica, pois o descompasso entre o Direito formalmente válido e a realidade social conduziu, de acordo com Celso Lafer, a uma mudança no paradigma da Filosofia do Direito que optou "pela redução da efetividade do sistema jurídico em relação aos seus destinatários, a um deslocamento de foco de

56. Cf. Allan Farnsworth. op. cit., pp. 25.

57. Cf. Amoldo Wald. Curso de Direito Civil Brasileiro: introdução c parte geral. $8^{a} \mathrm{~cd}$. Sào Paulo: Revista dos Tribunais, 1995, pp. 11-12.

58. Cf. Tćrcio Sampaio Fcrraz Júnior. "Tcoria da Norma Jurídica: um modclo pragmático". A Norma Juridica coordenação de Sćrgio Fcrraz. Rio de Janciro: Frcitas Bastos, 1980, pp. 7-8. 
análise da norma para o momento de sua aplicação e este deslocamento fez com que a identificiação dos problemas da atividade juridica pelos jusfilósofos deixasse de ficar adstrita a configurações sistemáticas de ordem normativa e passasse a levar em conta a determinação de seu sentido" s?

Celso Lafer explica que "o que importa é deixar claro que o surgimento e o triunfo da idéia de direitos humanos na esfera doméstica dos Estados se inserem em um longo processo de amadurecimento de concepções de natureza ética, centradas nos conceitos de dignidade humana e de universalidade do ser humano, acima de quaisquer particularismos" 60

Para Luiz Alberto Warat, "no trabalho juridico, os diversos profissionais (juizes, advogados, professores, promotores, doutrinadores) são fortemente influenciados pelo 'senso comum teórico' Trata-se de um pano de fundo que condiciona todas as atividades cotidianas. Sem ele não pode existir prática jurídica, isto é, não se tem como produzir decisões ou significados socialmente legitimáveis" e aprofundando a questão, o senso comum teórico representaria "um sistema de conhecimentos que organiza os dados da realidade, pretendendo assegurar a reprodução dos valores $e$ práticas predominantes. Trata-se de um discurso que oferece respostas que apenas aludem ao real e comandadas por interesses que tomam a forma de principios ou diretrizes" e, dessa maneira, "não é dificil ver que o senso comum teórico apresente um conjunto de questões onde as respostas já estão sobredeterminadas" enquanto " $o$ trabalho cientifico determina uma mudança de problemática em relação ao senso comum teórico, produzindo transformação desse saber ideológico" " ${ }^{1}$

É importante, como já salientamos, mostrar ao aluno o mundo em que vive, desvendando as técnicas de controle social, bem como discutindo com ele a quem serve o conteúdo do que ensinamos.

No entanto, vamos lembrar também que temos um "calcanhar-deaquiles" com José Wilson Ferreira Sobrinho, o preparo didático, quase sempre negligenciado nos cursos de pós-graduação, pois “o preparo didático do professor

59. Cf. Cclso Lafer. A Reconstrução dos Direitos Humanos: um diálogo com o pensamento de Hannah Arcndt. São Paulo: Companhia das Letras, p. 281.

60. Cf. Cclso Lafer. Comércio, Desarmamento, Direitos Humanos: reflexõcs sobre uma cxpcriência diplomática. São Paulo: Paz c Tcrra, 1999, p. 146.

61. Cf. Luiz Albcrto Warat. "O Senso Comum Tcórico dos Juristas". O Direito Achado na Rua. 3a cd. Josć Gcraldo de Sousa Júnior (org.). Brasilia: UNB, 1990, pp. 101-102. 
universitário será o responsável direto pelo seu sucesso ou pelo seu fracasso em termos de comunicação com os alunos. Isto ocorre porque será necessário, muitas vezes, modificar o comportamento didático em função da realidade representada por uma turma. Não se pode trabalhar com generalizações no campo da didática, uma vez que não dará certo. Cada turma tem um determinado perfil que é apenas seu. Agir mecanicamente, como se todas as turmas fossem iguais, significa uma elevada probabilidade de o comportamento didático do professor não render bons frutos, para ele e para os estudantes. Por isso mesmo o recurso das fichas amareladas pelo tempo é condenável na medida em que pretende se impor autoritariamente a todas as turmas, independentemente de suas peculiaridades. A ficha em si mesma considerada não pode ser afastada de modo apriorístico. O que se condena é o vezo universitário de elaborá-la em determinado momento e de se imaginar que ela é infensa ao tempo e às modificações legislativas" 62

Dessa maneira, um exemplo bem colocado, na época em que um evento relatado à matéria ocorreu ou, ainda, a constante inserção de novas teorias no conteúdo ministrado coloca a exigência de clareza sem perda da qualidade teórica.

Porém, a profundidade excessiva traz sempre um desafio, bastando lembrar a frase do romancista Anatole France: "sou como os riachos, sou claro porque sou pouco profundo"

Um alerta deve ser feito, pois o que ocorre, na verdade, é que a "profundidade" que por vezes alguns professores querem imprimir ao curso está mais próxima do exemplo dado anteriormente em que a professora do ensino fundamental pretendia discutir semiótica com os alunos (o mesmo tema que estudava em seu mestrado) do que propriamente com um ponto do programa que deva ser necessariamente abordado na graduação.

Outro aspecto importante é que não adianta apenas recriminar o aluno, assim como também não parece conveniente eximi-lo de suas responsabilidade, já que sua formação depende muito de seu empenho pessoal.

O corpo docente e o corpo discente não podem e não devem encarar-se mutuamente como adversários; no passado essa prática já ocorreu, incluindo críticas à disciplina dos alunos e também ao seu despreparo intelectual.

Como já dissemos acima, durante o Império, tanto no primeiro, quanto

62. Cf. José Wilson Ferreira Sobrinho. Metodologia do Ensino Juridico e Avalią̧ão em Direito. Porto Alcgre: Sérgio Antonio Fabris, 1997, p. 36. 
no segundo reinado, discutia-se muito a crise do ensino jurídico, o diretor da Faculdade de Direito de Olinda, padre Lopes Gama, ainda em 1838 dizia que " deficiência dos cursos fundamentais devia atribuir-se a lástima de tanto bacharel ignorante, que não sabe entender os próprios compêndios do curso e que, condecorados com um título acadêmico, são, alias, objeto do escárnio público, porque pouco ou nada distam de qualquer idiota, faltos das mais ordinárias noções de literatura, falando miseravelmente e escrevendo com imperdoáveis soleicismos, barbarismos e neologismos" 63

A disciplina também não era esquecida, vez que em ofício de $1^{\circ}$ de setembro de 1831, o diretor da Faculdade de Direito de São Paulo, José Arouche de Toledo Rendon, lembrava de seus tempos de Coimbra e lamenva ter caído em desuso a palmatória, dizendo ainda que "de minha parte só posso dizer a V. Exa. que, segundo voz pública, tem havido aprovações não merecidas. Os estudantes bons são os primeiros que acusam aos que deviam ser reprovados. Os moradores da cidade, que os conhecem e que vêem alguns passeando de dia e de noite, admiram-se quando lhes diz que foram aprovados" e "meus mestres de Coimbra podiam ser exatos no tempo do despotismo em que os estudantes, nem em particular se atreviam a atacar os lentes, mas hoje estamos em outro tempo. Convém, contudo, pôr as coisas no estado de os discípulos respeitarem aos mestres e estes fazerem os seus deveres, não aprovando os que não querem estudar e vêm aqui gastar o dinheiro de seus pais superfluamente" 64

Talvez, atualmente, reclamemos também da ausência de outras "palmatórias" a serem aplicadas em situações de indisciplinas e talvez não reclamemos da leitura de romances ou poesias (pelo contrário, talvez incentivássemos até a leitura de best-sellers para criar o hábito da leitura), mas reclamamos certamente da internet, da televisão, etc. Enfim, a comparação entre passado e presente certamente nos obriga a pensar...

O aspecto externo do aluno também merece discussão, pois o aluno do curso de Direito já apresenta uma mudança em sua aparência que o distingue dos demais alunos da Universidade, até porque sua aparência passa a integrar um conjunto que visa o convencimento do interlocutor.

63. Cf. Alberto Venâncio Filho. op. cit. p. 55.

64. O diretor foi nomeado por decreto de 13 de outubro de 1827. Alberto Venâncio Filho inforına que "José Arouche de Toledo Rendon que, nascido em São Paulo, recebera em Coimbra, em 30 de jutho de 1779 o grau de doutor em leis, e de volta a São Paulo ali exercera, por algum tempo, a advocacia, sendo, então, muito reduzido o número de diplomados" (Cf. Alberto Venâncio Filho. op. cit., pp. 39-45. 
Nesse ponto, Fábio Ulhôa Coelho sustenta que "o convencimento começa com a aparência fisica do orador. Progressivamente, o estudante de Direito vai experimentando mudanças em seu corpo. O seu jeito de vestir, de cortar os cabelos, de se sentar, de cumprimentar os outros, acabam se amoldando a um padrão incompletamente definido, mas certamente existente: o padrão do corpo retórico. $\dot{E}$ necessária uma boa capacidade de verbalização das idéias, mesmo para aqueles que, profissionalmente, se limitam a escrever. As roupas devem ser tradicionais e a postura não deve destoar delas" ${ }^{65}$

Finalizando, não podemos olvidar que o Direito deveria apresentar um mínimo ético, pois como já disse discutimos anteriormente, quando San Tiago Dantas discutia o conflito Demais Ciências x Direito, o dilema do Direito é justamente essa exigência que lhe é feita e, como aponta Francesco Carnelutti, "diz-se freqüentemente que o Direito representa um minimum ético. É verdade. Se a quisermos compreender facilmente, podemos nos servir desta fórmula insuperável da ética cristã: fazer ou não-fazer aos outros aquilo que se quereria feito ou-não a si mesmo" e "o conteúdo desta fórmula, que exprime inteiramente a simplicidade e a imensidade da ética, só em parte (podemos dizer que só metade dele) penetra no Direito" ${ }^{6}$

A ética, nesse contexto, não deveria ser apenas uma disciplina a mais a ser ensinada no curso, mas sim a própria essência do mesmo, pois discutir o Direito deveria também ser a discussão da ética e, se existisse a disciplina há mais tempo, em todas as faculdades de Direito não presenciaríamos a existência de tantos profissionais da área verdadeiramente nefastos em nosso País.

\section{Conclusões}

1. A permanência do conflito no seio das sociedades tem se mostrado, infelizmente, como algo constante. As regras de convivência, estabelecidas ou-não pelo Estado, continuarão a existir e, obviamente, o sancionamento a quem viola tais regras. Portanto, o estudo da norma continuará a ser relevante, assim como a existência de um profissional que domine essas normas e tenha condições de aplicá-las ao caso concreto. Além disso, não podemos nos esquecer que o alardeado enfraquecimento do Estado é sempre cíclico.

65. Cf. Fábio Ulhôa Coelho. Lógica Jurídica: uma introdução. São Paulo: Educ, 1992, p. 119.

66. Cf. Francesco Carnelutti. Teoria Geral do Direito. tradução de Antonio Carlos Ferreira. São Paulo: Lejus, 1999, p. 131. 
2. Deve existir sempre a sintonia entre o Direito e a liberdade, pois a segurança almejada em períodos de centralização em torno do Estado não pode levar, como no passado, a um período de arbítrio, pois seria, tomando aqui emprestadas as palavras do jurista Fábio Konder Comparato, substituir a insegurança da desordem pela ordem da insegurança.

3. Do operador do Direito cada vez mais serão exigidos saberes múltiplos, pois interpretação da norma dependerá, cada vez mais, de conhecimentos meta-jurídicos, tais como a Biologia (Direito Ambiental) ou a Economia (Direito Empresarial ou o Direito do Consumidor), em vista da crescente utilização, nos textos legais, de conceitos oriundos de outras ciências. Além disso, um microssistema jurídico (como é o caso do Direito do Consumidor) pressupõe também um conhecimento prévio de outras disciplinas (Direito Civil, Direito Administrativo, Direito Processual Civil, Direito Penal, Direito Constitucional), necessidade que cria uma contradição, pois a excessiva produção legislativa gera também a necessidade, cada vez maior, de especialização do operador do Direito em uma determinada área.

4. O Ensino Jurídico deve ser constantemente oxigenado por novas críticas e reflexões, sem que se esqueçam as lições pretéritas; isso porque, como vimos, muito do que é apresentado como essencialmente novo já foi defendido no passado.

São Paulo, março de 2001. 
Bibliografia

ALVES, Rubem. Estórias de Quem Gosta de Ensinar. 17ª ed. São Paulo: Cortez, 1994.

ANTUNES, Paulo de Bessa. Direito Ambiental. $2^{\text {a }}$ ed. Rio de Janeiro: Lumen Juris, 1998.

ASSIER-ANDRIEU, Louis. O Direito nas Sociedades Humanas. tradução de Maria Ermantina Galvão. São Paulo: Martins Fontes, 2000.

BECCARIA, Cesare. Dos Delitos e Das Penas. tradução de Torrieri Guimarães. São Paulo: Hemus, 1990.

BITTAR, Carlos Alberto. Direitos do Consumidor: Código de Defesa do Consumidor. $4^{\mathrm{a}}$ ed. Rio de Janeiro: Forense Universitária.

BOBBIO, Norberto. A Era dos Direitos. $11^{\text {a }}$ ed. tradução de Carlos Nelson Coutinho. Rio de Janeiro: Campus, 1992.

CAENEGEM, R. C. Uma Introdução Histórica ao Direito Privado. tradução de Carlos Eduardo Machado. São Paulo: Martins Fontes, 1995.

CAMPILONGO, Celso Fernandes. Direito e Democracia. São Paulo: Max Limonad, 1997.

. Direitos Humanos, Direitos Sociais e Justiça. José Eduardo Faria (org.). São Saulo. Malheiros, 1998.

CAPPELLETTI, Mauro. "Formações Sociais e Interesses Coletivos diante da Justiça Civil” Revista de Processo n. 5, p. 128-159.

CARMONA, Carlos Alberto. Arbitragem e Processo: um comentário à Lei n. 9.307/96. São Paulo: Malheiros, 1998.

CARNELUTTI, Francesco. Teoria Geral do Direito. tradução de Antonio Carlos Ferreira. São Paulo: Lejus, 1999.

CHOMSKY, Noam. A Minoria Próspera e a Multidão Inquieta. 2ª ed. Brasília: UNB, 1999.

COELHO, Fábio Ulhôa. Lógica Jurídica: uma introdução. São Paulo: Educ, 1992.

COMPARATO, Fábio Konder. Para Viver a Democracia. São Paulo: Brasiliense, 1989.

COUTURE, Eduardo. Os Mandamentos do Advogado. $3^{\text {a' }}$ ed. tradução de Ovídio A Baptista da Silva e Carlos Otávio Athayde. Porto Alegre: Sérgio Antonio Fabris, 1987. 
DALLARI, Dalmo de Abreu. Direitos Humanos e Cidadania. São Paulo: Moderna, 1998.

DANTAS, San Tiago. "A Educação Jurídica e a Crise Brasileira". Encontros da UNB: Ensino Jurídico. Brasília: UNB, 1978-1979.

DINIZ, Maria Helena. "A Ectogênese e seus Problemas Jurídicos" Revista do Programa de Pós-Graduação da Faculdade de Direito da Pontificia Universidade Católica de São Paulo - PUC-SP. n. 1. São Paulo: Max Limonad, 1995. p. 89-99.

FARIA, José Eduardo. A Reforma do Ensino Juridico. Porto Alegre: Sérgio Antonio Fabris, 1987.

São Paulo. Malheiros, 1998.

. Direitos Humanos, Direitos Sociais e Justiça. José Eduardo Faria (org.).

. O Direito na Economia Globalizada. tese apresentada no concurso para professor titular do Departamento de Filosofia e Teoria Geral do Direito da Faculdade de Direito da Universidade de São Paulo. Edição do Autor. s.d.

FARNSWORTH, E. Allan. Introdução ao Sistema Jurídico dos Estados Unidos. tradução de Antonio Carlos Diniz de Andrada. Rio de Janeiro: Forense, 1963.

FERRAZ JÚNIOR, Tércio Sampaio. "Teoria da Norma Jurídica: um modelo pragmático". A Norma Jurídica coordenação de Sérgio Ferraz. Rio de Janeiro: Freitas Bastos, 1980.

FERREIRA FILHO, Manoel Gonçalves. Direitos Humanos Fundamentais. São Paulo: Saraiva, 1995.

LAFER, Celso. A Reconstrução dos Direitos Humanos: um diálogo com o pensamento de Hannah Arendt. São Paulo: Companhia das Letras, 1988.

Comércio, Desarmamento, Direitos Humanos: reflexões sobre uma experiência diplomática. São Paulo: Paz e Terra, 1999.

LEBRUN, Gerard. O que é Poder? São Paulo: Brasiliense, 1984.

LEITE, Eduardo de Oliveira. "A Aula em Direito" Seis Temas sobre o Ensino Jurídico. organizada por Getulino do Espírito Santo Maciel e João Bosco da Encarnação. São Paulo: Robe Editorial, 1995.

LISBOA, Roberto Senise. Contratos Difusos e Coletivos: Consumidor, MeioAmbiente, Trabalho, Agrário, Locação, Autor. São Paulo: Revista dos Tribunais.

LOPES, José Reinaldo. O Direito na História: lições introdutórias. São Paulo: Max Limonad, 2000.

LORENZETTI, Ricardo Luis. Fundamentos do Direito Privado. São Paulo: Revista dos Tribunais, 1998. 
MARTIN, Ana Paula Nascimento. "A Alternativa da Arbitragem". Debatendo Direito: jornal do centro acadêmico XI de Agosto da Faculdade de Direito da Universidade de São Paulo. n. 13. São Paulo, 2000. pp. 23-25.

MILARÉ, Édis. Direito do Ambiente: doutrina, prática, jurisprudência, glossário. São Paulo: Revista dos Tribunais, 2000.

MONTORO, André Franco. Estudos de Filosofia do Direito. $2^{\text {i }}$ ed. São Paulo: Saraiva, 1995.

MORE, Thomas. A Utopia tradução de Luís de Andrade. Bauru: Edipro, 1994.

NASCIMENTO, Walter Vieira. Lições de História do Direito. 9"a ed. Rio de Janeiro: Forense, 1997.

NERY JÚNIOR, Nélson. Código Brasileiro de Defesa do Consumidor comentado pelos autores do anteprojeto. $6^{\prime \prime}$ ed. coord de Ada Pelegrini Grinover. Rio de Janeiro: Forense Universitária, 1999. Arts. 46 a 54.pp. 429-555.

. Principios do Processo Civil na Constituição Federal. $3^{\text {a }}$ ed. São Paulo: Revista dos Tribunais, 1996.

PERLINGIERI, Pietro. Perfis do Direito Civil: Introdução ao Direito Civil Constitucional. tradução de Maria Cristina De Cicco. $3^{\text {in }}$ ed. Rio de Janeiro: Renovar, 1.997.

PIOVESAN, Flávia. Direitos Humanos e o Direito Constitucional Internacional. $4^{i a}$ ed. São Paulo: Max Limonad, 2000.

RIBEIRO, Maurício Portugal. “O Direito Contemporâneo e a Metodologia do Ensino do Direito". Direito Global. coord. Carlos Ari Sundfeld e Oscar Vilhena Vieira. São Paulo: Max Limonad, 1999.

ROUSSEAU, Jean-Jacques. O Contrato Social. tradução de Antônio de P. Machado. Rio de Janeiro: Edições de Ouro, 1971.

SILVA, Ezequiel Theodoro. Magistério e Mediocridade. $2^{i 1}$ ed. São Paulo: Cortez, 1993.

SOUZA, Luiz Sérgio Fernandes de. "Globalização e Direitos Humanos: em busca da racionalidade perdida" RT-757 - novembro de 1998. pp. 52-63.

TELLES JÚNIOR, Goffredo. O Direito Quântico: ensaio sobre o fundamento da ordem jurídica. 6“ ed. São Paulo: Max Limonad, 1985.

VENÂNCIO FILHO, Alberto. Das Arcadas ao Bacharelismo. $2^{\text {: }}$ ed. São Paulo: Perspectiva, 1982.

WALD, Arnoldo. Curso de Direito Civil Brasileiro: introdução e parte geral. $8^{:}$ ed. São Paulo: Revista dos Tribunais, 1995. 
Breves Considerações sobre o fitturo do profissional do Direito: a crise do Estado, as

Alterações de ordem interdisciplinar e a crise do ensino juridico

WANDERLEY, Luiz Eduardo W. O que é Universidade. São Paulo: Círculo do Livro (encadernação por licença editorial da Editora Brasiliense S/A), 1992.

WARAT, Luiz Alberto. "O Senso Comum Teórico dos Juristas" O Direito Achado na Rua. $3^{\text {a }}$ ed. José Geraldo de Sousa Júnior (org.). Brasília: UNB, 1990. pp. 101-104.

WITKER, Jorge. O Direito na América Latina: conteúdo e ensino. tradução de Manuela Leandro. Coimbra: Centro de Estudos Jurídicos, 1975. 